\title{
BLENDED LEARNING INSTRUCTIONAL DESIGN DEVELOPMENT ON THE PREPACKAGED PRODUCTS TRAINING USING PEDATI MODEL
}

\author{
Wicaksono Febriantoro \\ wicaksono.f@gmail.com \\ Ministry of Trade, Republic of Indonesia
}

\begin{abstract}
Civil State Apparatus (ASN) Act No. 52014 stated that ASN have the right to gain competence development. Further in PP No.11 2017 on Civil Servant Management confirmed that every government officer is entitled to competence development for at least 20 (twenty) lesson hours in 1 (one) year.Limited metrological technical training allocationcauses not all ASN in Indonesia have the opportunity to develop their competence. Therefore, it is necessary to develop varieties of metrological trainings in addition to conventional methods. The alternative is e-learning based training. One of its goal is to reduce face to face lesson hour, as a result more technical training can be conducted by PPSDK without compromising training quality. This study will analyzed the development of blended learning design that is tailored to the training needs and characteristics of participants in government institutions with prepackaged products training case study using PEDATI model. Research and development (R\&D) methods with descriptive qualitative approach is used in this study. Design outcomes are as follows: all stages in PEDATI model can be used to develop blended learning instructional design based on validation by subject matter experts. A recommendation in the 4th stage the design of asynchronous learning activities should include time allocation for each learning activity in order to estimate the total time required. Accurate learning activity mapping into synchronous and asynchronous learning can ensure the achievement of competence standard and simultaneously reducing time needed to conduct face to face learning. The design prune face to face learning activity from total 50 Learning Hours (5 days) to only 20 Learning Hours ( 2 days), but as the trade off training participants have to occupy longer time in online activities.
\end{abstract}

Keywords: instructional design; blended learning; PEDATI model 


\section{INTRODUCTION}

Indonesian government through bureaucracy reform program try to improve their government officer competence continuously. Recently enacted regulation stated that every government officer (ASN) in Indonesia have the right to increase their capacity and expertise for at least 20 (twenty) lesson hours in 1 (one) year. Unfortunately not all ASN have the luxury of attending competence development by their training institution. PPSDK as Echelon II unit of the Ministry of Commerce dealing with Metrological Human Resource Development in Indonesia continuously conducts competency development program through various types of training held annually. Training organized including functional and technical training. At this moment, the functional training lasted for 2.5 months while technical training lasted for 5 days in average. PPSDK organizes technical training as media to upgrade metrological human resource capability in Indonesia through conventional training method (classical). This method was the easiest to conduct for trainer and students, however it has several drawbacks, one of them is limited training quota due to its face to face compulsory activities. These training conducted as much as 20 times a year with the quota of 30 people/training. This means that in a year PPSDK can train 600 people, while the need for training in Indonesia that is consist of 514 districts / cities x 2 (minimum person) that is 1028 people. There is still a difference of 428 people between the capacity of training and training needs of metrological human resource in Indonesia. In the other side, data from wearesocial shows that per January 2018 internet users in Indonesia reach the 132.7 million with a penetration rate of $50 \%$ of population (population 262 million). Active social media users data of 130 million while registered smartphone users a total of 177.9 million or $67 \%$ of the total population. From this survey also found active user of social media which access using mobile devices, namely an amount of 120 million inhabitants (wearesocial, hootsuite, 2018). Higher internet use is triggered by the development of infrastructure and the ease of getting a smartphone or handheld device.

Based on those conditions, required a variety of models for metrological training with the involvement of information, communication and technology (ICT)to overcome the deficit. One option of the proposed training model is e-learning based training (full elearning and blended learning). The goal is to reduce the face to face lesson hour as a result more technical training can be conducted by PPSDK without compromising training quality. For instance, 20 training/year x 5 days/training $=100$ days/year, if we can reduce classroom activities to 2 days, it means that we can have 100 days/year: 2 days = approximately 50 training/year $=50 \times 30=1500$ people (increased significantly comparing to conventional training).

As an early stage, the research will try to design blended learning instructional design in one metrological training subject. Through Blended Learning method, trainer and training participants gradually adapt to the advancement of educational technology but still supported by the usual method of face to face. Blended learning is not merely upload learning material to internet and tell the students to learn from it, but trainer has to make sure that instructional design is made as clear as possible in order to achieve the competence standard. In the other words, learning activities that should be done by students have to be stated clearly. 


\section{LITERATURE REVIEW}

Research on blended learning design has been done quite a lot, among others by Mabed and Koehler (2012) using the concept of Taxonomy Bloom and Gagne and Alammary, Sheard and Carbone (2014) which classify blended learning design into 3 (low, medium and high impact) based on the potential changes in learning programs and student learning experiences, in Indonesia some research conducted by Prayitno (2015) which provides examples of the implementation of blended learning in primary and secondary schools.

The design of blended learning design in a more systematic way in college has been done by Chaeruman U. A. (2012), (2013) and (2017). The study used models from Kemp, Morrison, \& Ross (1994) as a rationale covering 4 components of learning design, i.e learning participants, learning objectives, learning methods and assessment of learning process. Then in the determination of learning achievement criteria using the Mager model (1984), Donald, (1999) and Dick, Carey and Carey (2005). Selection of learning settings through synchronous and asynchronous activities using a combination of Dale's cone of experience (1969), Smaldino \& Lowther (2012) learning modality and Bloom's Taxonomy (1956). This model was an improvement to existing blended learning instructional design that already implemented in Indonesia Online Learning System (SPADA). In 2017, SPADA is conducted in 6 Facilitator University along with 32 Partner University and consist of 17 subject enrolled by 1746 students (Chaeruman U. A., PEDATI Model Desain Sistem Pembelajaran Blended. Panduan Merancang Mata Kuliah Daring SPADA Indonesia, 2017). This approach is called PEDATI model which illustrated in figure 1.

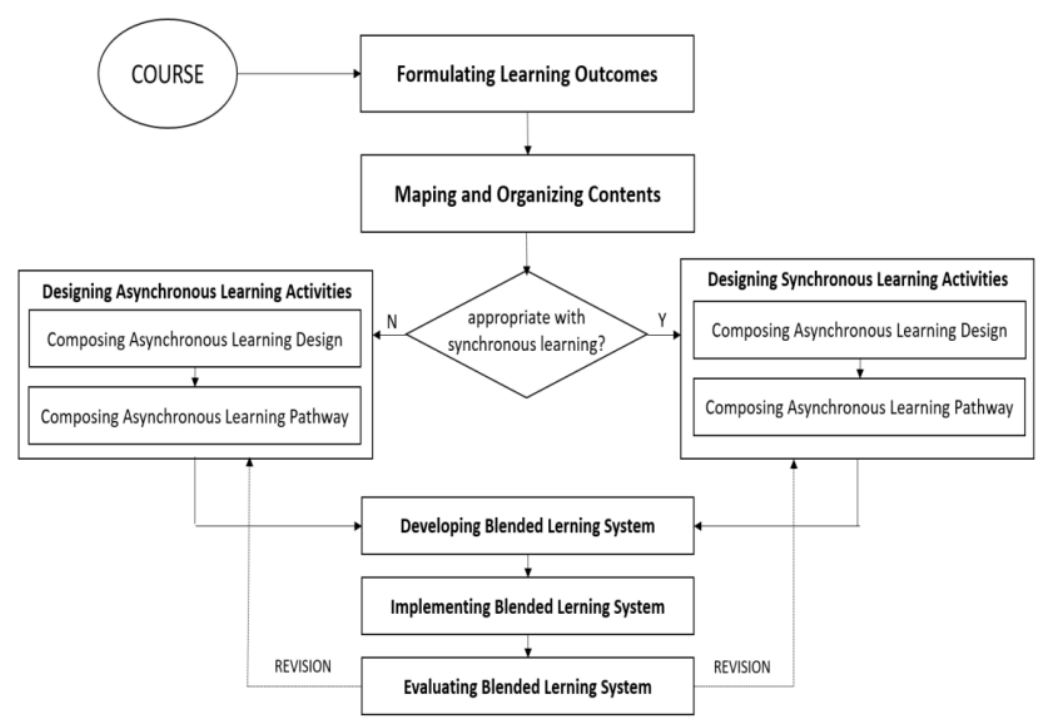

FIGURE1. Blended Learning System Design(Chaeruman, Wibawa, \& Syahrial, Blended Learning System Design Model, 2017) 
The PEDATI model in Fig. 1 is an acronym of Learning- Deepening-ApplyingEvaluating or in Indonesian Pelajari-Dalami-Terapkan-Evaluasi (a cycle of learning paths offered in a blended learning system). This model was developed by Chaeruman, Wibawa, \& Syahrial (2017).

The PEDATI component consists of the following five main steps:

1. Formulate learning achievement

2. Mapping and Organizing Learning Materials

3. Choosing and Determining Synchronous and Asynchronous Learning Activities

4. Designing Asynchronous Learning Activities

5. Designing Synchronous Learning Activities

However, setting of those research mostly in colleges and schools that have the needs, learning objectives, context and characteristics of participants different from the training process in government agencies like depicted in table 1.

TABLE 1.Preliminary Analysis of PEDATI Model (compiled from various sources and regulations)

\begin{tabular}{|c|c|c|}
\hline $\begin{array}{c}\text { Aspects of PEDATI } \\
\text { Model }\end{array}$ & College/University & $\begin{array}{l}\text { Government Training } \\
\text { Center (PPSDK, } \\
\text { Ministry of Trade) }\end{array}$ \\
\hline Requirements & - & - \\
\hline $\begin{array}{l}\text { Learning } \\
\text { Objectives }\end{array}$ & $\begin{array}{l}\text { Predefined Learning } \\
\text { Outcomes }\end{array}$ & Competence Standard \\
\hline $\begin{array}{l}\text { Participants } \\
\text { Characteristic }\end{array}$ & $\begin{array}{l}\text { Students with Quite similar } \\
\text { age group 17-30 }\end{array}$ & $\begin{array}{l}\text { Government officer } \\
(\text { ASN) with Various } \\
\text { range of age from 20-50 }\end{array}$ \\
\hline Context & $\begin{array}{l}\text { - Long time learning } \\
\text { - Semester (6 month) / } 16 \\
\text { weeks } \\
\text { - Flexible Time to learn } \\
\text { online }\end{array}$ & $\begin{array}{l}\text { - Short Time } \\
\text { - Daily-Weekly basis } \\
\text { - Less Flexible Time to } \\
\text { learn online }\end{array}$ \\
\hline
\end{tabular}

From table 1 we can surmise that learning in university is different with learning in government training center seen from member attribute and learning context. Most of university student are in similar age group (17-30) while training participants in government training center have various range of age (20-50). Learning context also different, while learning in university has long term $( \pm 16$ weeks), learning in government training center has shorter time (daily/weekly). University student also have more flexible time to learn comparing to government training participant that have to work from 8 a.m to 4 p.m every day. Therefore, this study aims to develop and analyzed blended learning design that is tailored to the training needs and characteristics of participants in government institutions with prepackaged products training case study using PEDATI model. 


\section{METHODOLOGY}

Research and development (R\&D) methods with descriptive qualitative approach are used in this study as shown in the Fig.2. Research and Development Method is a research method used to produce a particular product, and test the effectiveness of the product (Sugiyono, 2015). The R \& D method with descriptive qualitative approach is used with the aim to develop the existing learning design (conventional / face-to-face) into blended learning design for prepackaged product supervision training through qualitative instruments.

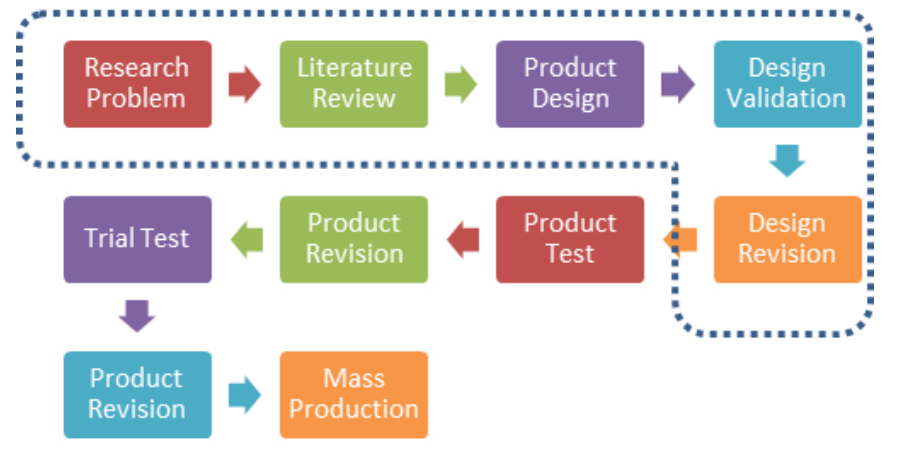

FIGURE2. R \& D Research Procedure (Sugiyono, 2015)

In this study, as can be seen in table 2, after conducting literature review regarding blended learning instructional design and metrological training subject case study (prepackaged product supervision) researcher will try to map competence standard of prepackaged product supervision in to PEDATI model to analyze whether it is suitable or not. After instructional design finished, validation conducted by subject matter expert through focus group discussion. Revision (if any) is made based on the design validation conducted by the experts. Due to research scope, this study is limited to design revision only. 
TABLE 2.Data Collection and Research Instrument

\begin{tabular}{|c|c|c|c|c|}
\hline No & Data/Information Obtained & Source & $\begin{array}{l}\text { Data } \\
\text { Collection } \\
\text { Technique }\end{array}$ & $\begin{array}{l}\text { Research } \\
\text { Instrument }\end{array}$ \\
\hline 1 & $\begin{array}{l}\text { Blended Learning } \\
\text { Concept/Theory/Framework, } \\
\text { Blended Learning Instructional } \\
\text { Design Model }\end{array}$ & $\begin{array}{l}\text { Journals, } \\
\text { Conference } \\
\text { Proceedings, } \\
\text { Books, } \\
\text { Regulation }\end{array}$ & $\begin{array}{l}\text { Literature } \\
\text { Review }\end{array}$ & \\
\hline 2 & $\begin{array}{lr}\text { Prepackaged } & \text { Product } \\
\text { Supervision } & \text { Competence } \\
\text { Standard } & \\
\end{array}$ & $\begin{array}{ll}\text { Ministry of } \\
\text { Trade } \\
\text { Regulation }\end{array}$ & $\begin{array}{l}\text { Literature } \\
\text { Review }\end{array}$ & \\
\hline 3 & $\begin{array}{l}\text { Evaluation/Validation } \\
\text { blended learning model } \\
\text { have been developed }\end{array}$ & $\begin{array}{l}\text { Subject Matter } \\
\text { Expert }\end{array}$ & $\begin{array}{l}\text { Focus Group } \\
\text { Discussion } \\
\text { (FGD) }\end{array}$ & $\begin{array}{l}\text { Discussion } \\
\text { Guideline }\end{array}$ \\
\hline
\end{tabular}

\section{FINDING AND DISCUSSION}

Based on Figure 1 The PEDATI Component consists of five main steps as follows:

1. Formulate learning achievement

Referring to the Mager model (1984), Clark (2010), Kemp (2013), Dick, Carey \& Carey (2015), learning achievement should contain four elements A (audience), B (behaviour), $\mathrm{C}$ (condition) and D (degree). Formulation of learning achievement for the training of Supervision of Prepackaged Products from competence standard, namely:

After participating in prepackaged products supervisory training session, training participants can carry out prepackaged product supervision including monitoring of labeling compliance and testing the quantity of weight and volume prepackaged product in accordance with applicable regulations.

2. Mapping and Organizing Learning Materials

There are 3 elements of competence from training of supervision of prepackaged products which is administrasion and technical preparation, perform labelling surveillance and prepackaged product quantity testing and the last one is evaluation and reporting. For research purpose we will explore more the $2^{\text {nd }}$ elements of competence because it has various performance criteria that hopefully can represents asynhcronous and synchronous learning. Learning Materials are derived from elements of competence and performance criteria in the form of subject matter as presented in table 3 . 
TABLE 3. Mapping and Organizing Learning Materials Example

\begin{tabular}{|c|c|c|c|}
\hline No & Elements of Competence & Performance Criteria & Subject Matter \\
\hline \multirow[t]{4}{*}{1} & \multirow[t]{4}{*}{$\begin{array}{l}\text { Perform labelling } \\
\text { surveillance and prepackaged } \\
\text { product quantity testing at the } \\
\text { time of production (Pre } \\
\text { Market) and on the market / } \\
\text { based on result of complaint } \\
\text { (Post Market) }\end{array}$} & $\begin{array}{l}\text { 1.1 Labelling and quantity } \\
\text { testing of Pre and Post } \\
\text { Market is done based on the } \\
\text { provisions in force; } \\
\text { 1.2 The results of labelling } \\
\text { surveillance } \\
\text { prepackaged quantity } \\
\text { testing of Pre and Post } \\
\text { Market recorded in the } \\
\text { form. }\end{array}$ & $\begin{array}{l}\text { Label Provisions Based on } \\
\text { Trade Ministerial } \\
\text { Regulation No.31 } 2011 \text { and } \\
\text { No.26 } 2017 \text { on } \\
\text { prepackaged products. } \\
\text { 2. The Nominal Quantity of } \\
\text { Letters and Numbers (label) } \\
\text { 3. Writing Measurement } \\
\text { Symbol Unit and examples. }\end{array}$ \\
\hline & & $\begin{array}{l}\text { 1.3 The quantity testing results } \\
\text { calculated and processed } \\
\text { based on a statistical } \\
\text { parameter; }\end{array}$ & $\begin{array}{l}\text { 4. Prepackaged Product } \\
\text { Testing Procedure (Director } \\
\text { General Decree No.26 } 2015 \\
\text { on Prepackaged Product } \\
\text { Testing Guidance -Weight } \\
\text { \& Volume) } \\
\text { 4.1 Sampling Techniques } \\
\text { 4.2 Terms of Prepackaged } \\
\text { Product Testing } \\
\text { 4.3 Prepackaged Product } \\
\text { Testing in Weight } \\
\text { 4.4 Prepackaged Product } \\
\text { Testing in Volume }\end{array}$ \\
\hline & & $\begin{array}{l}\text { 1.4Prepackaged products that } \\
\text { are not in accordance with } \\
\text { regulation installed with } \\
\text { metrology line for security } \\
\text { reason. }\end{array}$ & $\begin{array}{l}\text { 5. Procedures for Metrology } \\
\text { Line Installation and } \\
\text { Making of Prepackaged } \\
\text { Products Supervision } \\
\text { Minutes }\end{array}$ \\
\hline & & $\begin{array}{l}\text { 1.5The prepackaged product } \\
\text { supervisory report shall be } \\
\text { made in accordance with } \\
\text { the applicable format. }\end{array}$ & \\
\hline
\end{tabular}

3. Choosing and Determining Synchronous and Asynchronous Learning Activities The next step is to determine the synchronous and asynchronous learning settings. Based on the methods of Edgar Dale (1966), Smaldino (1999) and Bloom then consideration of the selection and determination of relevant learning activities can be described with question as follows: 
- To achieve performance criteria or subject matter, whether it requires implementation and practice directly ? if yes, then such learning can be achieved by direct synchronous learning activity or face to face.

- If not, students simply read, hear, see, watch and participate in certain learning activities, then the learning can be achieved through asynchronous learning activities.

The example of learning activity mapping can be seen in table 4 as follows :

TABLE 4. Learning Activity Mapping Example

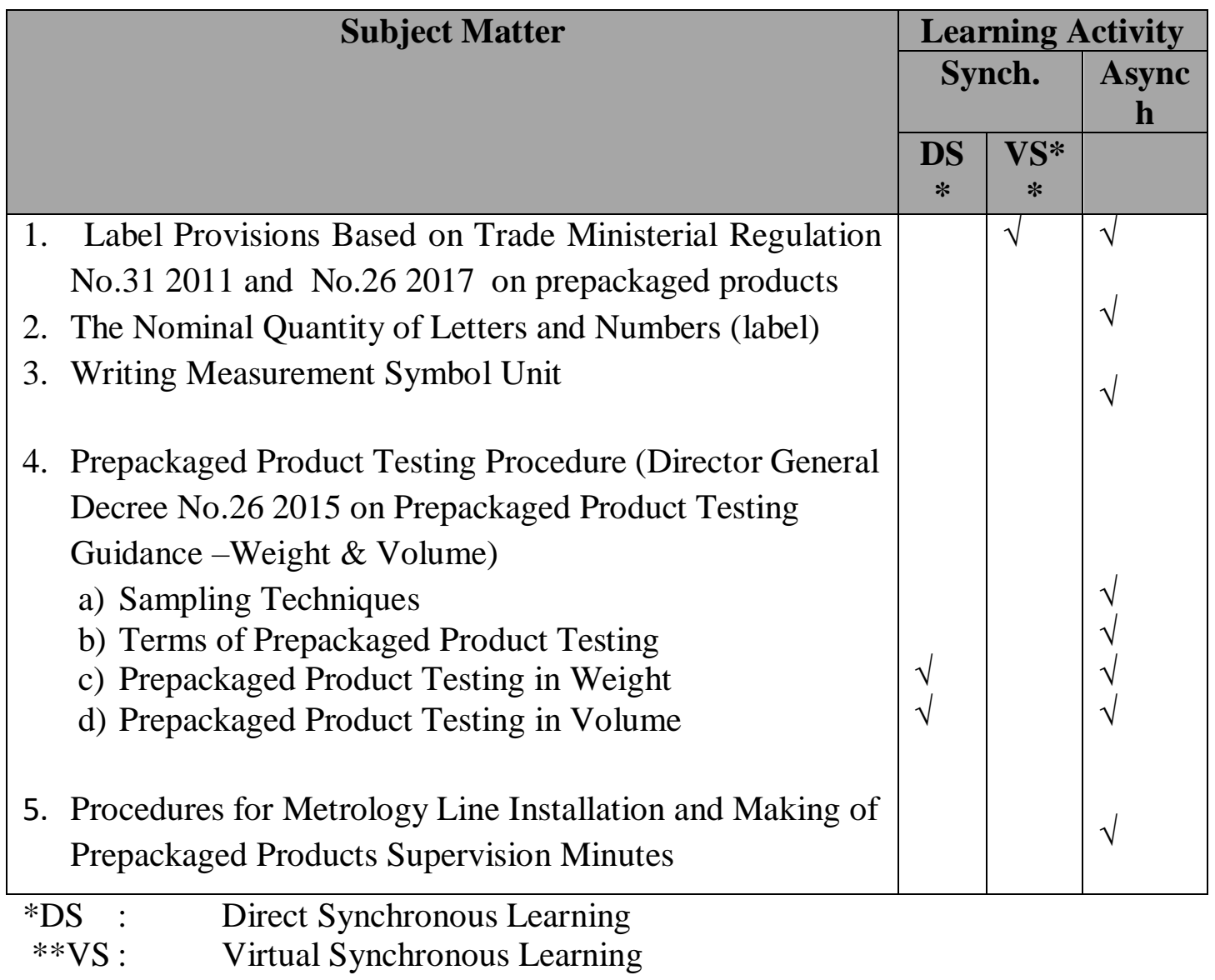

4. Designing Asynchronous Learning Activities

After the learning activity is mapped, the next step is designing asynchronous learning activities, including:

1) Arrange the design of asynchronous learning activities;

Covers material, objective tests, online discussion forums and assignments as an asynchronous learning assessment. There are four things to understand: online learning path, learning object, criteria of selecting relevant media and assessment in asynchronous learning. 
According to selection criteria and determination of digital media / asset based on work of Merril (1998) and Smaldino (1999), digital media divided by text, audio, visual, video, animation and simulation. Each of these media are suitable to certain knowledge variety. For instance : to explain procedure can be delivered by text or audio, but it will be easier to understood if provided by video or animation. Last but not least are Assessment, related to what extent students master the learning achievement of competence standard that have been set. The instruments that can be used are as follows:

Non objective test: by Online discussion forums and Online Assignment Objective Test : by Multiple Choice, Matching, True/False, Short Answer.

Thus, based on these references, the design of asynchronous learning activities of subject matter 1-3 can be seen in table 5 as follows:

TABLE 5.Design of asynchronous learning activities

\begin{tabular}{|c|c|c|c|c|}
\hline \multirow[t]{4}{*}{ Subject Matter } & \multicolumn{4}{|c|}{ Asynchronous Learning Strategy } \\
\hline & \multicolumn{2}{|c|}{ Self Directed Asynchronous } & \multicolumn{2}{|c|}{$\begin{array}{l}\text { Collaborative } \\
\text { Asynchronous }\end{array}$} \\
\hline & & & Evaluation & \\
\hline & Digital Media & Test & $\begin{array}{c}\text { Online } \\
\text { Discussion }\end{array}$ & $\begin{array}{c}\text { Online } \\
\text { Assignmen } \\
\mathbf{t}\end{array}$ \\
\hline $\begin{array}{lr}\text { 1. Label Provisions } \\
\text { Based on Trade } \\
\text { Ministerial } \\
\text { Regulation No.31 } \\
2011 \text { and No.26 } \\
2017 \text { on } \\
\text { prepackaged } \\
\text { products } \\
\text { 2. The Nominal } \\
\text { Quantity of Letters } \\
\text { and Numbers } \\
\text { (label) } \\
\text { 3. Writing } \\
\text { Measurement } \\
\text { Symbol Unit }\end{array}$ & $\begin{array}{l}\text { 1. Video of } \\
\text { Labelling } \\
\text { Provision based } \\
\text { on Trade } \\
\text { Ministerial } \\
\text { Regulation No.31 } \\
2011 \text { and No.26 } \\
2017 \\
\text { Presentation } \\
\text { Slide including } \\
\text { example of } \\
\text { supervision form } \\
\text { result (ppt file) } \\
\text { Document (.pdf } \\
\text { file) of } \\
\text { Trade Ministerial } \\
\text { Regulation } \\
\text { No.31 2011 and } \\
\text { No.26 2017 }\end{array}$ & $\begin{array}{l}\text { 2. Labellin } \\
\text { g Case } \\
\text { Study }\end{array}$ & $\begin{array}{l}\text { Analyze } \\
\text { prepackaged } \\
\text { product } \\
\text { labelling } \\
\text { minimum } \\
\text { requirement }\end{array}$ & $\begin{array}{l}\text { Simulating } \\
\text { prepackage } \\
\text { d product } \\
\text { labelling } \\
\text { supervision } \\
\text { using } \\
\text { example } \\
\text { that already } \\
\text { been set, } \\
\text { then upload } \\
\text { the result }\end{array}$ \\
\hline
\end{tabular}


PEDATI model has not explain further about time allocated for each subject matter/learning activities. Based on class experience, for subject matter 1 to 3 , the time needed are 2, 2 and 1 Learning Hours (LH) respectively.

2) Construct an asynchronous learning pathway that includes instruction (instructional direction), description (explanation), a series of independent asynchronous activities (digital media and quizzes / tests) and a series of collaborative asynchronous activities (discussion forums and online assignments) assembled in such a way inductively or deductive into an interactive learning object, interesting and can produce the optimal learning experience possible. The learning path example of Prepackaged Product Supervision for subject matter 1-3 can be seen in table 6 as follows:

TABLE 6. The learning path example of Prepackaged Product Supervision

\begin{tabular}{|c|c|c|}
\hline No & Event/Agenda & Detailed Instruction \\
\hline 1 & Instruction & $\begin{array}{l}\text { One of the legal metrology supervisor task is prepackaged } \\
\text { product supervision which includes monitoring the suitability of } \\
\text { labeling and quantity testing. In this session we will learn about } \\
\text { the provisions of labeling based on Minister of Trade Regulation } \\
\text { No.31 } 2011 \text { and No. } 262017 \text { that previously has been read } \\
\text { through the following video. Let's watch together. }\end{array}$ \\
\hline 2 & Digital Media & $\begin{array}{l}\text { The previously created Video (uploaded on Youtube) explaining } \\
\text { the labeling requirements under Minister of Trade Regulation } \\
\text { No. } 31 \text { of } 2011 \text { and No.26 } 2017 \text { including the provision of letters } \\
\text { and numbers and the writing of unit symbols }\end{array}$ \\
\hline 3 & Instruction & $\begin{array}{l}\text { Is it already understood with the stipulation of prepackaged } \\
\text { labeling based on Minister of Trade Regulation No. } 312011 \text { and } \\
\text { No. } 26 \text { 2017? If you are still confused please review the video or } \\
\text { discuss with the trainer or fellow training participants through } \\
\text { the following discussion forum: }\end{array}$ \\
\hline 4 & $\begin{array}{l}\text { Discussion } \\
\text { Forum }\end{array}$ & $\begin{array}{l}\text { Interactive Discussion Analyze Minimum Terms that must be } \\
\text { listed in the prepackaged label }\end{array}$ \\
\hline 5 & Instruction & $\begin{array}{l}\text { After studying the videos and deepening labeling through } \\
\text { discussion forums, to further internalize the labeling supervision, } \\
\text { please apply the labeling controls on the prepackaged product } \\
\text { examples around you (not necessarily the same as each student). } \\
\text { Then send the results through the following task media. }\end{array}$ \\
\hline 6 & $\begin{array}{l}\text { Media } \\
\text { Assignment }\end{array}$ & Insert Assignment that accommodates students' work \\
\hline 7 & Instruction & $\begin{array}{l}\text { The final step in the series of labeling supervision is evaluation / } \\
\text { assessment. This is done through online tests of multiple choice } \\
\text { and case studies. Please do according to your understanding }\end{array}$ \\
\hline
\end{tabular}




\begin{tabular}{|l|l|l|}
\hline No & Event/Agenda & \multicolumn{1}{c|}{ Detailed Instruction } \\
\hline 8 & $\begin{array}{l}\text { Online } \\
\text { Assessment }\end{array}$ & $\begin{array}{l}\text { Online test is a multiple choice and case study to measure } \\
\text { students understanding toward material that has been given }\end{array}$ \\
\hline
\end{tabular}

3) Digital Media Requirement Identification

Based on learning path that already been made, the next step is identfying digital media requirements. We can see in table 7 the identification of such media for subject matter 1-3 as follows :

TABLE 7. Digital Media Requirement Identification Example

\begin{tabular}{|c|c|c|c|}
\hline Subject Matters & $\begin{array}{c}\text { Media } \\
\text { Requirements }\end{array}$ & Media Type & Total \\
\hline $\begin{array}{l}\text { Based on Trade } \\
\text { Ministerial }\end{array}$ & Text & $\begin{array}{l}\text { Minister of } \quad \text { Trade } \\
\text { Regulation No.31 2011 } \\
\text { and 26 2017 (pdf file) }\end{array}$ & 2 \\
\hline \multirow[t]{2}{*}{$\begin{array}{lr}\text { Regulation } & \text { No.31 } \\
2011 \text { and } & \text { No.26 } \\
2017 & \text { on } \\
\text { prepackaged } & \\
\text { products } & \end{array}$} & Visual & $\begin{array}{l}\text { Presentation } \\
\text { including example of } \\
\text { supervision form result } \\
\text { (ppt file) }\end{array}$ & 1 \\
\hline & Audio & - & \\
\hline \multirow{4}{*}{$\begin{array}{l}\text { 2. The Nominal } \\
\text { Quantity of Letters } \\
\text { and Numbers (label) }\end{array}$} & Audio-Visual & Video & 1 \\
\hline & $\begin{array}{l}\text { Animation } \\
\text { Simulation/Games }\end{array}$ & - & \\
\hline & Assessment & Test/Quiz & 2 \\
\hline & & Discussion Forum & 1 \\
\hline $\begin{array}{l}\text { 3. Writing } \\
\text { Measurement } \\
\text { Symbol Unit }\end{array}$ & & Assigment & 1 \\
\hline \multicolumn{3}{|c|}{ TOTAL } & 8 \\
\hline
\end{tabular}

After conducting identification for all subject matters, next phase is to develop digital media (i.e video). Developing digital media is not included in this research.

5. Designing Synchronous Learning Activity

As stated in table 4, there are 2 subject matter that will be conduct in synchronous learning which is prepackaged product testing in weight and volume. To give better understanding of synchronous learning activity, we will analyze more in subject matter 4.c in table 4 namely prepackaged product testing in weight.

1) Designing Direct Synchronous Learning Activity can be seen in table 8 . 
TABLE 8.Direct Synchronous Learning Activity Design

\begin{tabular}{|c|c|c|c|c|}
\hline $\begin{array}{l}\text { Subject } \\
\text { Matters }\end{array}$ & Methods & Media & $\begin{array}{c}\text { Time } \\
\text { Allocation } \\
\text { (LH) }\end{array}$ & Assessment \\
\hline $\begin{array}{l}\text { Prepackage } \\
\text { d Product } \\
\text { Testing in } \\
\text { Weight }\end{array}$ & Lab Work & $\begin{array}{l}\text { Lab Tools : } \\
\text { 1. Wipes and } \\
\text { tissues } \\
\text { 2. Testing } \\
\text { Form } \\
\text { 3. Standard } \\
\text { Weights } \\
\text { 4. Electronic } \\
\text { Scales }\end{array}$ & $\begin{array}{l}5 \\
(2 \\
\text { group/LH), } \\
10 \text { groups, } \\
\text { max. } 3 \\
\text { persons/gro } \\
\text { up }\end{array}$ & $\begin{array}{l}\text { Group } \\
\text { Assignment : Lab } \\
\text { Work and Filling } \\
\text { Testing Form }\end{array}$ \\
\hline
\end{tabular}

2) Designing Virtual Synchronous Learning Activity

Basically the same with direct synchronous learning activity, the difference is their implementation where learning resources are at a different location with the participants of the study. The learning process is carried out with the process of video conference or webinar. In the context of blended learning, virtual synchronous learning activities is optional, meaning that it can be done and can also not done according to the situation and condition. In this phase, virtual synchronous learning will be conduct to strengthen the understanding of subject matter 1 which is labelling regulation. Example of design of virtual synchronous learning for labelling regulation can be seen in table 9 as follows: 
TABLE 9. Virtual Synchronous Learning Activity Design

\begin{tabular}{|c|c|c|c|c|}
\hline $\begin{array}{l}\text { Subject } \\
\text { Matters }\end{array}$ & Method & Media & $\begin{array}{c}\text { Time } \\
\text { Allocati } \\
\text { on }\end{array}$ & Assessment \\
\hline $\begin{array}{l}\text { Label } \\
\text { Provisions } \\
\text { Based on } \\
\text { Trade } \\
\text { Ministerial } \\
\text { Regulatio } \\
\text { n No.31 } \\
2011 \text { and } \\
\text { No.26 } \\
2017 \text { on } \\
\text { prepackag } \\
\text { ed } \\
\text { products }\end{array}$ & $\begin{array}{l}\text { 1. Talkshow : } \\
\text { Labelling } \\
\text { Regulation } \\
\text { Review } \\
\text { 2. Question and } \\
\text { Answer of } \\
\begin{array}{lr}\text { Provisions } & \text { Babel } \\
\text { on } & \text { Trade } \\
\text { Ministerial } & \\
\text { Regulation } & \text { No.31 } \\
2011 \text { and } & \text { No.26 } \\
2017 & \text { on } \\
\text { prepackaged } \\
\text { products }\end{array}\end{array}$ & $\begin{array}{l}\text { Video } \\
\text { Conferenc } \\
\text { e/Webinar }\end{array}$ & $\begin{array}{l}2 \text { Lesson } \\
\text { Hours } \\
\text { (LH) }\end{array}$ & $\begin{array}{l}\text { Given Case Study } \\
\text { Problem concerning } \\
\text { Label Provisions } \\
\text { starting } \\
\text { preparation, from } \\
\text { implementation and } \\
\text { evaluation (including } \\
\text { labelling supervision } \\
\text { form) }\end{array}$ \\
\hline
\end{tabular}

The next step is to arrange the learning path (learning plan) in more detail per subject as follows.

1. Direct Synchronous Learning Flow can be seen in table 10 :

TABLE 10. Direct Synchronous Learning Flow

\begin{tabular}{|c|c|c|}
\hline $\begin{array}{l}\text { Type of } \\
\text { Activity }\end{array}$ & Learning Activity & $\begin{array}{c}\text { Time } \\
\text { Allocation } \\
\text { (Lesson } \\
\text { Hour) }\end{array}$ \\
\hline Introduction & $\begin{array}{l}\text { Trainer reviewing the Weight Prepackaged } \\
\text { testing procedure including, sampling } \\
\text { technique, and prepackaged testing (MPE and } \\
\text { lot acceptance) with question and answer } \\
\text { method }\end{array}$ & \multirow[t]{3}{*}{ 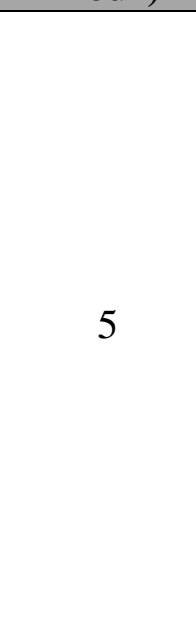 } \\
\hline $\begin{array}{l}\text { Main } \\
\text { Activity }\end{array}$ & $\begin{array}{l}\text { Laboratory work through group assignment }(2 \\
\text { group/LH, } 10 \text { groups, max. } 3 \text { persons/group): } \\
\text { 1. Conduct prepackaged product testing in } \\
\text { weight } \\
\text { 2. Filling Testing Form } \\
\text { 3. Calculate test result }\end{array}$ & \\
\hline Closing & $\begin{array}{l}\text { Trainer take } 1 \text { group example to check testing } \\
\text { form, calculate test result and discuss together. }\end{array}$ & \\
\hline & TOTAL TIME ALLOCATION & 5 \\
\hline
\end{tabular}


2. Virtual Synhronous Learning Flow The following example through webinars/video conference with method of interactive dialogue between trainer as a Presenter and followed the Q \& A with training participants presented in table 11 as follows.

TABLE 11. Virtual Synchronous Learning Flow

\begin{tabular}{|l|l|l|l|l|}
\hline Subject Matter & Presenter & \multicolumn{1}{|c|}{ Method } & \multicolumn{1}{|c|}{ Media } & \multicolumn{1}{c|}{$\begin{array}{c}\text { Time } \\
\text { Allocation }\end{array}$} \\
\hline $\begin{array}{l}\text { Label Provisions } \\
\text { Based on Trade } \\
\text { Ministerial }\end{array}$ & Trainer & $\begin{array}{l}\text { Presentation }+ \\
\text { Interactive } \\
\text { dialogue }\end{array}$ & $\begin{array}{l}\text { Presentation } \\
\text { Slide + Video }\end{array}$ & LH \\
$\begin{array}{l}\text { Regulation No.31 } \\
2011 \text { and No.26 } \\
2017 \text { on prepackaged } \\
\text { products }\end{array}$ & & & & \\
\hline
\end{tabular}

Finishing synchronous learning activity design, we can summarize blended learning model for all subject matter from prepackaged product supervision training as illustrated in table 12:

TABLE 12.Blended Learning Syllabus for Prepackaged Product Supervision Training

\begin{tabular}{|c|c|c|c|c|}
\hline No & Subject Matter & $\begin{array}{l}\text { E-Learning } \\
\text { (LH) }\end{array}$ & $\begin{array}{c}\text { Face to Face } \\
\text { (Theory + Lab } \\
\text { Work) (LH) } \\
\end{array}$ & $\begin{array}{l}\text { Total } \\
\text { (LH) }\end{array}$ \\
\hline 1 & $\begin{array}{l}\text { Label Provisions } \text { Based on } \\
\text { Trade Ministerial Regulation } \\
\text { No.31 } 2011 \text { and No.26 } 2017 \\
\text { on prepackaged products }\end{array}$ & $\begin{array}{c}4(2 \\
\text { Asynchronous } \\
+2 \text { Webinar })\end{array}$ & & 4 \\
\hline 2 & $\begin{array}{l}\text { The Nominal Quantity of } \\
\text { Letters and Numbers (label) }\end{array}$ & 2 & & 2 \\
\hline 3 & $\begin{array}{l}\text { Writing Measurement Symbol } \\
\text { Unit }\end{array}$ & 1 & & 1 \\
\hline 4 & $\begin{array}{l}\text { Prepackaged Product Testing } \\
\text { Procedure (Director General } \\
\text { Decree No.26 } 2015 \text { on } \\
\text { Prepackaged Product Testing } \\
\text { Guidance-Weight \& Volume) }\end{array}$ & & & \\
\hline & a. Sampling Techniques & 5 & & 5 \\
\hline & $\begin{array}{l}\text { b. Terms of Prepackaged } \\
\text { Product Testing }\end{array}$ & 5 & & 5 \\
\hline
\end{tabular}




\begin{tabular}{|l|l|c|c|c|}
\hline No & \multicolumn{1}{|c|}{ Subject Matter } & $\begin{array}{c}\text { E-Learning } \\
(\text { LH) }\end{array}$ & $\begin{array}{c}\text { Face to Face } \\
(\text { Theory + Lab } \\
\text { Work) }(\text { LH) }\end{array}$ & $\begin{array}{c}\text { Total } \\
(\text { LH) }\end{array}$ \\
\hline & $\begin{array}{l}\text { c. Prepackaged Product } \\
\text { Testing in Weight }\end{array}$ & 5 & 5 & 10 \\
\hline $\begin{array}{l}\text { d. Prepackaged Product } \\
\text { Testing in Volume }\end{array}$ & 5 & 5 & 10 \\
\hline 5. & $\begin{array}{l}\text { Procedures for Metrology Line } \\
\text { Installation and Making of } \\
\text { Prepackaged Products } \\
\text { Supervision Minutes }\end{array}$ & 3 & & 3 \\
\hline 6. & Competence Test & $\mathbf{3 0}$ & $\mathbf{2 0}$ & $\mathbf{5 0}$ \\
\hline & TOTAL & & \\
\hline
\end{tabular}

As shown in table 12, blended learning model can minimize face to face learning activity from total $50 \mathrm{LH}$ (5 days) to only $20 \mathrm{LH}$ (2 days). The reduction can be more significant depending on how accurately trainer divide subject matter in to synchronous and asynchronous learning.

After designing all the stages of PEDATI model, validation through focus group discussion (FGD) among the subject matter experts are conducted with several results as follow:

1) Learning achievement in PEDATI model is fit with the title of competence unit of training.

2) Learning activity mapped correctly to divide subject matter into synchronous and asynchronous learning.

3) Determination of digital media in asynchronous learning is suitable, considering resource availability such as: time, effort and cost.

4) Need to determine time allocation for each activity in asynchronous learning (digital media, online discussion, online assignment, and online test).

5) Virtual synchronous learning activity is optional, if there is not enough resource (time, effort and costs) then we do not have to conduct such activity.

6) Need further test and trial to evaluate the design effectiveness in achieving competence standard.

The interesting matter to be featured in this study is the knowledge and skill to map learning activity correctly. Precise learning activity mapping into synchronous and asynchronous learning can make sure the achievement of competence standard and in the same time reducing time needed to conduct face to face learning. From the FGD with subject matter experts we can get the information that video is playing pivotal role on asynchronous learning, instead of telling students to read learning material that often get bored, they will get better understanding and enjoy more if they can watch the video demonstration. According to Smaldino (Smaldino \& Lowther, 2012), students mastery of certain topics are depends on the learning experience they had. For instance, they will master $10 \%$ of the topic if they read text, $20 \%$ if they listen to lecture, $30 \%$ if they watch 
picture and 50\% if they watch video/exhibit/demonstration on certain topic. In addition, students can rewind the video, learn according to their pace and also can watch repeatedly. Video is also more feasible and efficientin term of producing cost comparing to animation (2D/3D), augmented and virtual reality media. Watching video supported by interactive forum discussion, real case study assignment and evaluate through direct practical experience are considered to be one of the best method to achieve competence standard through blended learning method.

Another important point is regarding the time allocated for asynchronous learning, with non conventional method (learning can be anytime and anywhere as long as there is internet connection), students can learn in their convenience time and place. Hence the trainer has to state learning hours of asynchronous learning and then the learner can manage to allocate their time wisely. A question thus arised, how many hours/day should be allocated by students? In this case study, the students are government officer which have work hours/day i.e 8.00 A.M to 4.00 P.M. On several government training institution that already conduct blended and online learning, they recommend maximum 2 to 3 learning hours/day to learn. They can do it before, during or after working time each day according to their convenience. As a result, in the trade off for reducing face to face activity, the students may have more time to spend on e-learning depends on how many subject matter and activities that delivered online. In this case, face to face meeting can reduced to only 2 days meeting $(20 \mathrm{LH})$, before that they have to conduct e-learning activities for $30 \mathrm{LH}$ divided by $3 \mathrm{LH} /$ day so overall they have to study online for 10 days +2 days meeting.

\section{CONCLUSION}

Based on the research and development of instructional design that have been described previously, the researcher draw the following conclusion:

1. Every part of PEDATI model can be used to generate blended learning instructional design in prepackaged product supervision training based on validation by subject matter experts. A suggestion for PEDATI model in the 4th phase the design of asynchronous learning activities should comprehend time allocation for each learning activity so that trainer can approximate the total time required,

2. Precise learning activity mapping into synchronous and asynchronous learning can assure the fulfillment of competence standard and in the same time reducing time needed to held face to face learning. From the case study, more than $50 \%$ subject matters can be delivered by asynchronous learning activity. It means that only subject matter which need laboratory practice and direct evaluation/assessment are conducted by conventional method, thus reducing classroom lesson hour. Consequently, students will spent more time in e-learning activities.

3. Video plays essential part of the asynchronous learning, as a result need to develop multimedia based learning material that can help increase student mastery and suits the students characteristic.

4. Need further test and trial of the model effectiveness toward competence standard achievement. Optimum time needed for each subject matter in asynchronous 
learning also have to be evaluated. The test and trial will be conduct in the next phase of this research (after developing video based learning material).

\section{REFERENCES}

Alammary, A., Sheard, J., \& Carbone, A. (2014). Blended learning in higher education: Three different design. Australasian Journal of Educational Technology.

Bloom, B. S., \& Engelheart, M. D. (1956). Taxonomy of educational objectives: The classification of educational goals. Handbook I: Cognitive domain. New York: David McKay Company.

Chaeruman, U. A. (2012). Blended Learning : A Framework Model for Lecturer. International Symposium of Open, Distance and e-Learning. Bali.

Chaeruman, U. A. (2013). Merancang Blended Learning yang membelajarkan. Seminar Nasional "Meningkatkan Kualitas Pembelajaran Melalui Sumber-Sumber dan Teknologi yang Tepat". Surakarta: UNS.

Chaeruman, U. A. (2017). PEDATI Model Desain Sistem Pembelajaran Blended. Panduan Merancang Mata Kuliah Daring SPADA Indonesia. Direktorat Pembelajaran, Dirjen Pembelajaran dan Kemahasiswaan, Kemenristekdikti.

Chaeruman, U. A., Wibawa, B., \& Syahrial, Z. (2017). Blended Learning System Design Model. Third International Conference on Innovation in Education - ICIE . Bangkok: Mahidol University.

Dale, E. (1969). Audiovisual methods in teaching.

Donald, C. R. (1999). Bloom's Taxonomy of Learning Domains.

Kemp, J. E., Morrison, G. R., \& Ross, S. (1994). Designing Effective Instruction. New York: MacMillan College Publ.Co.

Mabed, M., \& Koehler, T. (2012). An Instructional Design for Developing an Effective Blended Learning Environment. EDULEARN12 Conference. Barcelona.

Mager, R. F. (1984). Developing Attitude Toward Learning (2nd ed.). Atlanta: GA: The Center for Effective Performance Inc.

Prayitno, W. (2015). Implementasi Blended Learning dalam Pembelajaran pada Pendidikan Dasar dan Menengah. Jurnal Pendidikan, Volume VI No.01.

Prayitno, W. (2015). Penerapan Blended Learning dalam Pengembangan Pendidikan dan Pelatihan bagi Pendidik dan Tenaga Kependidikan. Jurnal Pendidikan, Vol VI No.2.

Smaldino, S. E., \& Lowther, D. L. (2012). Instructional Technology \& Media for Learning. Jakarta: Kencana.

Sugiyono. (2015). Metode Penelitian \& Pengembangan. Alfabeta.

Walter, D., Carey, L., \& Carey, J. O. (2005). The Systematic Design of Instruction (6th edition). Boston: MA : Pearson.

wearesocial, hootsuite. (2018). Digital in 2018 : Southeas Asia, A Study of Internet, Social Media, and Mobile Use Througout the Region. wearesocial. 
